\title{
Evaluation Index System of Corporation's Innovation Capacity and Application Study
}

\author{
Xuezhen Hong1, Yingzhong Wang ${ }^{2}$ \\ ${ }^{1}$ Department of Management, Jinan University, Guangzhou, China \\ ${ }^{2}$ Sino-French Institute, Renmin University of China, Beijing, China \\ Email:1059211071@qq.com,vincentwangyz@yahoo.com
}

How to cite this paper: Hong, X.Z. and Wang, Y.Z. (2016) Evaluation Index System of Corporation's Innovation Capacity and Application Study. Technology and Investment, 7, 143-151.

http://dx.doi.org/10.4236/ti.2016.74016

Received: October 24, 2016

Accepted: November 20, 2016

Published: November 23, 2016

Copyright $\odot 2016$ by authors and Scientific Research Publishing Inc. This work is licensed under the Creative Commons Attribution International License (CC BY 4.0).

http://creativecommons.org/licenses/by/4.0/

\begin{abstract}
Innovation is the precondition for the sustainable development of corporation, and the purpose of "reform of the supply front" which the government puts forward at present is to improve the innovation capacity of corporation. In this paper, in order to provide reference for improving innovation capacity and seek the factor of improving the innovation capacity, an evaluation index system of corporation's innovation capacity is established after analyzing the input, profit, steady finance and governance capacity of the corporations which are listed on the Growth Enterprises Market by comparing the score of each corporation's innovation capacity.
\end{abstract}

\section{Keywords}

Innovation Capacity, Evaluation Index, Enlightenment, Analytic Hierarchy Process

\section{Introduction}

Since reform and opening-up, great changes have happened and people's life is getting better and better in China. Export, investment and consumption have been a troika of economic development all the time. Relatively, investment and exports contribute more, and consumption makes less contribution. However, the time is gone and the contradictions in China' economics is changing. Now supply can't keep up with demand, which is the important obstacle of economic growth. Under the background of the mismatch between supply and demand, President Xi Jinping put forward "reform of the supply front" at the 11th meeting of the central finance and economy leading group on Nov 10,2015 , which told us to expand moderately aggregate demand, in the meantime, to strengthen structural reform of the supply front, increase the quality and efficiency of supply system and provide a growth impetus for sustainable economic development. In particular, it requires us to clean the zombie industry, eliminate backward production 
capacity and transfer the development to the emerging field of innovation for economic growth. Therefore, it is necessary to improve the innovation capacity of enterprises for their persistent development.

Austrian-American economist Schumpeter in 1912 was first proposed an innovative idea that innovation is the essence of economic development. Based on the idea that Schumpeter put forward, many scholars at home and abroad began to research the innovation of the enterprises and put forward all kinds of meaningful explanations. In a word, innovation is the soul of a nation's progress and the driving force for the prosperity of a country. Hence, it is meaningful for a country to research corporation's innovation capacity. Only by knowing how to increase innovation capacity, can we improve the comprehensive level of the whole country. Most of the corporations which are listed on the Growth Enterprises Market (GEM) are engaged in high-tech business and have high growth. They were usually founded for a short time and have not outstanding performance. However, there is a lot of space to grow up for them. In this paper, we use the data of the corporations which are listed on the GEM to evaluate their innovation capacity.

\section{Literature Review}

There are various evaluation indexes and methods to evaluate corporation's innovation capacity according to different perspectives of scholars. Some evaluation methods are commonly used at home and abroad. Such as regression analysis, principal component analysis, back-propagation artificial network, fuzzy synthetic evaluation, data envelopment analysis, gray relational analysis, factor analysis, etc. And each method has its advantages and disadvantages.

John Hagrdoorn and Myriam Cloodt (2003) began to use multiple and composite index which was considered to reflect the innovation capacity better in order to make up for shortcomings of individual index. Hence, they selected the following indicators to measure corporation's innovation capacity: expenditure on $R \& D$, the number of patents, patent citation and the number of new products [1]. Carayannis and Provance (2008) focused on the input, process and performance which was called 3P framework when evaluating the corporation's innovation capacity [2]. Souitaris (2002) and Caloghirou (2004) selected the regression analysis to evaluate the innovation capacity by analyzing the relation between various factors that affect innovation and performance, and demonstrating the validity of the regression analysis through various tests. But the method places a greater demand on quantitative data, especially on time series data which is a disadvantage [3] [4].

In China, Jiang Wei (1995) measured the innovation capacity from the perspective of innovation decision-making, $\mathrm{R} \& \mathrm{D}$, production, marketing and organization ability after studying the concept and structure of the corporation's innovation capacity. His view has made a contribution to represent the structure of innovation capacity through the process of innovation. However, his evaluation is too simple and not comprehensive for using only nine indexes [5]. Enhua $\mathrm{Hu}$ (2001) selected factor structure and di- 
vided indexes of technological innovation capacity into six factor groups by the process of implementing technological innovation. Each factor group was divided into four factors and there were twenty-four factors totally. First grade indexes were as follows: management, input, $R \& D$, manufacturing, sales and realization ability. However, he did not point out the selection standard and basis when applying the factor structure, and it was difficult to evaluate some factor, such as the ability of getting information, which was deficient [6]. Qingyun Wang (2004) considered that there were many factors affecting technological innovation performance and most of them were grey fuzzy and hard to quantify. Evaluation was much subjective for it was based on the knowledge, cognition and preference of evaluators. While the grey system theory whose mathematical method was nonstatistical was widely used in complex mechanism and more levels, and was reflected its value in use more easily on the condition that the system data was little or factors did not meet the requirement of statistics. So the author chose the grey theory system to construct the comprehensive evaluation model [7]. Weili Xia (2005) divided evaluation system of innovation capacity into five first grade indexes which were as follows: $R \& D$, input, organization and management, marketing and finance ability. The index system was simple and some of them were subjective, such as leaders' desire for innovation [8].

\section{Construction for Index System of Innovation}

\subsection{Principle of Construction}

Some principles are needed to be considered when constructing the evaluation system. This paper takes science, systematization, comparability and operability principles into consideration when constructing the innovation index system of the corporations which are listed on the GEM.

\subsection{Choice of Index}

This paper constructs a new evaluation index system of corporation's innovation capacity which can be seen in Table 1 after considering the principle of construction and reading previous research for reference.

Innovation capacity is divided into input capacity, profit capacity, steady finance capacity and governance capacity in this paper. Development expenditure and the Ratio of Sales Costs to Income belong to input capacity index. The Ratio of Sales Costs to In-

Table1. Evaluation index system of corporation's innovation capacity.

\begin{tabular}{ccc}
\hline Target Stratum & Criterion Level & Target Level \\
\hline & Input Capacity (w1) & Development Expenditure (w11) \\
& & The Ratio of Sales Costs to Income (w12) \\
Corporation's & Profit Capacity (w2) & ROA (w21) \\
Innovation Capacity & CPS2) & Cash Flow (w31) \\
& Steady Finance Capacity (w3) & Increase Rate of Main Business Revenue (w32) \\
& Governance Capacity (w4) & The Ratio of Independent Directors (w41) \\
& The Degree of Board Member (w42) \\
\hline
\end{tabular}


come represents the efficiency of the sales, and the more sales costs are, the less the sales ability is, that is, input capacity is weaker on the condition of the same income. And we regard ROA and EPS which represent a better profit capacity when they are large numbers as the index of profit capacity. Not only should we consider current situation, but also we need to observe the capacity change over time when evaluating the innovation capacity. Hence, this paper selects steady finance capacity as first grade index and increase rate of main business revenue as second grade. The system of independent directors is regard as a new innovation of corporation governance system which shows a good governance capacity when the ratio is high. Besides, the degree of board member that is high shows a good governance capacity. Therefore, the ratio of independent directors and the degree of board member are suitable to be governance capacity indexes.

\section{Empirical Analysis and Results}

\subsection{Sample Selection}

The most important feature of GEM is that it has low barrier to enter and it requires strict operation, which helps small and medium-sized corporations get financing opportunities and promote the corporations to develop. This paper selects all listed companies on GEM between 2012-2014 excluding the companies whose information is incomplete. There are 80 companies in 2012, 96 companies in 2013 and 103 companies in 2014 in total. The data above is from CSMAR data. Excel and Stata are used to deal with the data.

\subsection{Choice of Evaluation Index}

This paper selects the analytic hierarchy process (AHP) in order to overcome the disadvantage of subject weights when determining the weights of all indexes. The evaluation index of innovation capacity can be seen in Table 1. Development expenditure can be found in the non-current assets of balance sheet. ROE is the ratio of net profit to total assets in the end. EPS represents the earnings per share in income statement, and cash flow represents increase in cash and cash equivalents divided by total shares. Besides, the degree equals 1 if the board member is a bachelor's degree, 2 if the board member is a master's degree, 3 if the board member is a $\mathrm{PhD}$ degree and 0 otherwise. The degree of board member is the average of the degree mentioned above in this paper.

\subsubsection{Non-Dimension of Indicators}

Three common non-dimension methods are as follows: standardization method, maximum difference dormalization method and equalization method. This paper selects equalization method for variation degree of index can be eliminated easily by standardization method and maximum difference dormalization method can be affected by maximal and minimal value. Concrete operations are as follows:

$$
y_{i j}=\frac{x_{i j}}{\bar{x}_{j}}
$$

$y_{i j}$ represents the I company's value of $j$ index and $\bar{x}_{j}$ represents all the compa- 
nies' average of $j$ index.

\subsubsection{Forward Transformation of Index}

When the number of the index is big, some indexes called positive indexes show a better innovation capacity, while some indexes called contrary indexes show a worse innovation capacity. Besides, it's good for some indexes called moderate indexes to get close to a certain definite value. The ratio of sales costs to income called contrary index in this paper shows a weaker innovation capacity when the sales cost is high on the condition of the same income. Therefore, the ratio of sales costs to income is transformed forward after non-dimensionalization changing. Concrete operations as follows:

$$
y_{i j}{ }^{\prime}=-y_{i j}
$$

This transformation is a good choice for it will not change the distribution of the index.

Hence, the values of the indexes are all processed when measuring the innovation capacity. In addition, we need to transform forward the data after the equalization in order to keep the size relationship if the average of the index is negative.

\subsubsection{Construction for the Evaluation System of Innovation Capacity}

AHP was proposed by American operational research experts named T.L. Saaty in the mid-seventies of twentieth century. This paper grades the indexes after comparing them by asking experts for advice, constructs judgement matrix and calculates the weight of each index. The judgement matrix and weight of criterion level and target level can be seen in Table 2 and Table 3.

After calculating, we conclude that the weight of criterion level relative to target stratum is represented as follow: $\mathrm{a}=(0.071,0.368,0.368,0.193)$ and the weight of target level relative to level relative is represented as follow: $\mathrm{b} 1=(0.5,0.5), \mathrm{b} 2=(0.75,0.25)$, $\mathrm{b} 3=(0.167,0.833), \mathrm{b} 4=(0.25,0.75)$. Hence, the weight of target level relative to target stratum is $\mathrm{c}=(\mathrm{w} 11=0.035, \mathrm{w} 12=0.035, \mathrm{w} 21=0.276, \mathrm{w} 22=0.092, \mathrm{w} 31=0.061, \mathrm{w} 32=$ $0.307, \mathrm{w} 41=0.048, \mathrm{w} 42=0.145)$.

\subsubsection{The Results of Innovation Capacity of Corporations Listed on GEM}

This paper calculates innovation scores of corporations listed on GEM with the method

Table 2. The weight of criterion level.

\begin{tabular}{cccccc}
\hline Innovation Capacity & W1 & W2 & W3 & W4 & Weight \\
\hline W1 & 1 & $1 / 5$ & $1 / 5$ & $1 / 3$ & 0.071 \\
W2 & 5 & 1 & 1 & 2 & 0.368 \\
W3 & 5 & 1 & 1 & 2 & 0.368 \\
W4 & 3 & $1 / 2$ & $1 / 2$ & 1 & 0.193 \\
& & $\lambda_{\max }=4.0042, C I=0.0014, C R=0.0016,0.1$ & &
\end{tabular}


Table 3. The weight of target level.

\begin{tabular}{|c|c|c|c|}
\hline Input Capacity & W11 & W12 & Weight \\
\hline W11 & 1 & 1 & 0.5 \\
\hline W12 & 1 & 1 & 0.5 \\
\hline \multicolumn{4}{|c|}{$\lambda_{\max }=2, C I=0, C R=0<0.1$} \\
\hline Profit Capacity & W21 & W22 & Weight \\
\hline W21 & 1 & 3 & 0.75 \\
\hline W22 & $1 / 3$ & 1 & 0.25 \\
\hline \multicolumn{4}{|c|}{$\lambda_{\max }=2, C I=0, C R=0<0.1$} \\
\hline Steady Finance Capacity & W31 & W32 & Weight \\
\hline W31 & 1 & $1 / 5$ & 0.167 \\
\hline W32 & 5 & 1 & 0.833 \\
\hline \multicolumn{4}{|c|}{$\lambda_{\max }=2, C I=0, C R=0<0.1$} \\
\hline Governance Capacity & W41 & W42 & Weight \\
\hline W41 & 1 & $1 / 3$ & 0.25 \\
\hline W42 & 3 & 1 & 0.75 \\
\hline \multicolumn{4}{|c|}{$\lambda_{\max }=2, C I=0, C R=0<0.1$} \\
\hline
\end{tabular}

mentioned above and compares their innovation capacity. The top five and last five corporations in 2012, 2013 and 2014 can be seen in Table 4, Table 5 and Table 6, respectively.

\section{Conclusions and Enlightenment}

This paper constructs the evaluation index system of corporation's innovation capacity and ranks the corporations according to their scores. Chase Sun Pharmaceutical Co., Ltd. will be found in the top five both in 2012 and 2013 for it has increased the input capacity, constructed marketing team of existing products and adjusted the sales channels in the past two years, which helps to increase the sales ability and improve the sales of products. Therefore, it's in good operating conditions and operating income has grown substantially compared with last year. Besides, Chase Sun Pharmaceutical Co., Ltd. intensifies its research and development which leads to a situation that the cost of $\mathrm{R} \& \mathrm{D}$ has increased substantially within two years and capitalization of the cost accounts for a large proportion. The corporation continues improvement in governance, sets up reasonable professional structure of the members of the board and trains the member which asks them to master relevant laws and regulations. The corporation launches the first equity incentive plan in 2013, which is beneficial to further improve the structure of governance, perfect incentive mechanism, increase the innovation capacity and realize the maximization of the value of the company and shareholders eventually. 
Table 4. Scores of innovation capacity in 2012.

\begin{tabular}{|c|c|c|c|c|c|c|}
\hline \multicolumn{5}{|c|}{ The Top Five } & \multicolumn{2}{|c|}{ The Last Five } \\
\hline 1 & 300026 & Chase Sun Pharmaceutical Co., Ltd & 2.7256 & 300023 & Bode Energy Equipment Co., Ltd. & -0.3580 \\
\hline 2 & 300288 & Longmaster Information \& Technology Co., Ltd. & 2.6460 & 300091 & Jin Tong Ling Fluid Machinery Technology Co., Ltd & -0.2422 \\
\hline 3 & 300104 & Leshi Internet Information \& Technology Corp. & 2.0670 & 300051 & 35. com Technology Co., Ltd. & -0.1426 \\
\hline 5 & 300157 & Landocean Group Limited & 1.8734 & 300011 & Dinghan Technology Co., Ltd. & -0.0368 \\
\hline
\end{tabular}

Table 5. Scores of innovation capacity in 2013.

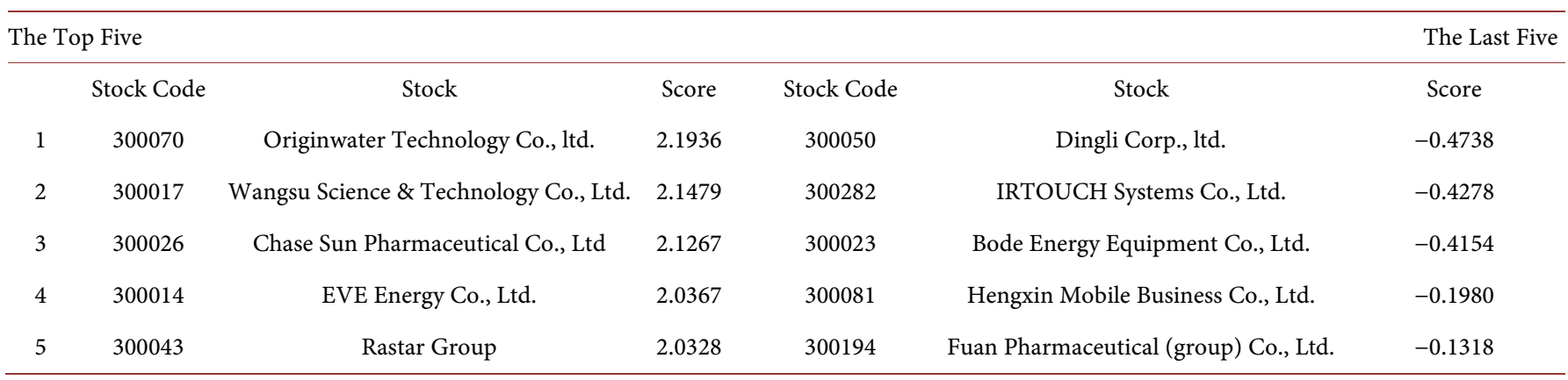

Table 6. Scores of innovation capacity in 2014.

\begin{tabular}{|c|c|c|c|c|c|c|}
\hline \multicolumn{5}{|c|}{ The Top Five } & \multicolumn{2}{|c|}{ The Last Five } \\
\hline 1 & 300282 & IRTOUCH Systems Co., Ltd. & 5.8975 & 300189 & Shennong Gene Technology Co., Ltd. & -0.6637 \\
\hline 2 & 300072 & Sanju Environmental Protection \& New Materials Co., Ltd. & 2.5472 & 300239 & Dongbao Bio-Tech Co., Ltd. & -0.1443 \\
\hline 3 & 300104 & Leshi Internet Information \& Technology Corp. & 2.4872 & 300167 & Dvision Video Communications Co., Ltd. & -0.0816 \\
\hline 5 & 300134 & Tatfook Technology Co., Ltd. & 1.8887 & 300191 & Sino Geophysical Co., Ltd. & -0.0273 \\
\hline
\end{tabular}

Originwater Technology Co., ltd. ranks in the top 5 in 2012 and 2013 for it actively broadens the market and focuses on membrane technology research, which causes a big increase in the total cost of R\&D. The corporation makes use of its own advantages of innovation technology to widen business and control the cost reasonably, which makes itself grow persistently and keep steady finance capacity. Meanwhile the corporation perfects the governance structure continuously and asks board members to train for mastering relevant regulations. The governance capacity has been improved and the overall profitability of the corporation will be strengthened ultimately.

Leshi Internet Information \& Technology Corp. develops effective marketing mode and strengthens the promotion of the brand continuously. It also constructs Letv ecosystem which includes platform, content, terminal and application to keep a rapid increase in business income. Hence, it ranks in the top 5 in 2012 and 2014. The corpora- 
tion strengthens the investment on the new product and new technology research in order to increase the innovation capacity. Gradually, it expands the overseas market. Its total spending on $\mathrm{R} \& \mathrm{D}$ accounts for a large proportion of revenues during the period. At the same time, there are two independent directors in five board members. And the corporation trains the managers in order to increase the level of governance.

IRTOUCH Systems Co., Ltd. ranks in the last 5 in 2013, while it ranks in the top 1 in 2014. There are some reasons listed as follow: the corporation invests heavily in 2014 and it optimizes the sales channels and sales promotion which is in favor of synchronous growth of sales revenue and net profit. Besides, the corporation increases the investment of $R \& D$ and has a lot of patents for invention that improves the competitiveness and maintains the steady finance capacity. In addition, it establishes a sound internal control system and perfects the structure of the governance in order to increase the level of managers. The innovation capacity is improved with the method mentioned above eventually.

This paper is intended to find a way to increase the innovation capacity of corporations and strengthen the national power. We can get some enlightenment from the analysis above: Only by increasing the investment, improving the steady finance capacity and perfecting the governance capacity, can we increase the profit capacity and achieve the goal of strengthening corporation' innovation capacity finally.

There are still some limitations in this paper: the innovation capacity of corporations is evaluated just based on four aspects, so it's not comprehensive enough. Four more aspects can be considered in future research. Besides, we just selected the corporations listed on GEM, maybe it's not representative enough. Other corporations can be researched to prove the credibility of the conclusion of this paper.

\section{References}

[1] Hagedoorm, J. and Cloodt, M. (2003) Measuring Innovative Performance: Is There an Advantage in Using Multiple Indicators. Research Policy, 32, 1365-1379. https:/doi.org/10.1016/S0048-7333(02)00137-3

[2] Ellias, G. and Provance, M. (2008) Measuring Firm Innovativeness: towards a Composite Innovation Index Built on Firm Innovative Posture, Propensity and Performance Attributes. International Journal of Innovation and Regional Development, 1, 90-107. https:/doi.org/10.1504/IJIRD.2008.016861

[3] Souitaris, V. (2002) Technological Trajectories as Moderators of Firm-Level Determinants of Innovation. Research Policy, 31, 877-898. https:/doi.org/10.1016/S0048-7333(01)00154-8

[4] Caloghirou, Y., Kastelli, I. and Tsakanikas, A. (2004) Internal Capabilities and External Knowledge Sources: Complements or Substitutes for Innovative Performance. Technovation, 24, 29-39. https:/doi.org/10.1016/S0166-4972(02)00051-2

[5] Wei, J. and Xu, Q.R. (1995) The Concept, Structure, Measurement and Evaluation of Corporation's Innovation Capacity. Scientific Management Research, 13, 50-55.

[6] Hu, E.H. (2001) The Construction and Comprehensive Evaluation of Index System of Corporation's Technology Innovation Capacity. Scientific Research Management, 22, 7984.

[7] Wang, Q.Y. and Rao, Y.D. (2004) Hierarchical Grey Comprehensive Judgment Model of 
Corporation's Technology Innovation Performance. Quantitative\& Technical Economics, 5, 55-62.

[8] Xia, W.L. and Lv, X.Q. (2005) The Evaluation and Application Study of Corporation's Innovation Capacity Based on BP Neural Network. R\&D Management, 17, 50-54.

Submit or recommend next manuscript to SCIRP and we will provide best service for you:

Accepting pre-submission inquiries through Email, Facebook, LinkedIn, Twitter, etc. A wide selection of journals (inclusive of 9 subjects, more than 200 journals)

Providing 24-hour high-quality service

User-friendly online submission system

Fair and swift peer-review system

Efficient typesetting and proofreading procedure

Display of the result of downloads and visits, as well as the number of cited articles

Maximum dissemination of your research work

Submit your manuscript at: http://papersubmission.scirp.org/

Or contact ti@scirp.org 